\title{
Laying performance and nitrogen balance in hens fed organic diets with different energy and methionine levels*
}

\section{J. Koreleski ${ }^{1}$ and S. Świątkiewicz}

\author{
National Research Institute of Animal Production, \\ Department of Animal Nutrition and Feed Science \\ 32-083 Balice, Poland
}

(Received 19 September 2008; revised version 3 November 2008; accepted 20 March 2009)

\begin{abstract}
In a model experiment, 72 Bovans brown hens from 24 to 53 weeks of age were allocated to 4 groups with 18 replicates. Each hen (replicate) was kept in an individual cage. Layers were fed basal organic diets with lower or higher metabolizable energy $\left(\mathrm{ME}_{\mathrm{N}}\right)$ contents resulting from including $1 \%$ rape seed oil. The diets formulated according to organic limitations on feedstuff choices were either not supplemented or supplemented with $0.6 \mathrm{~g} \cdot \mathrm{kg}^{-1}$ DL-methionine (Met) to increase total dietary methionine and SAA levels to $2.94 \mathrm{~g}$ and $5.21 \mathrm{~g} \cdot \mathrm{kg}^{-1}$, respectively. In the experiment, egg production, feed intake, feed conversion, egg quality parameters and nitrogen $(\mathrm{N})$ balance indices were determined.

Met supplementation of the diet had a positive effect on laying rate, feed intake and feed conversion $(\mathrm{P}<0.001)$. Egg and yolk weight were also increased by Met, but yolk contribution in egg was not changed. The higher energy level decreased daily feed intake, but had no effect on other performance parameters.

The increased dietary energy level positively affected $\mathrm{N}$ retention measured as $\%$ of $\mathrm{N}$ intake $(\mathrm{P}<0.05)$. Adding Met increased daily $\mathrm{N}$ retention $(\mathrm{P}<0.05)$ and $\mathrm{N}$ retention as $\%$ of $\mathrm{N}$ intake $(\mathrm{P}<0.01)$ and decreased $\mathrm{N}$ content in excreta $(\mathrm{P}<0.05)$, but the differences in daily $\mathrm{N}$ excretion were not confirmed statistically. Nevertheless, it could be calculated for the whole experimental period (350 days) that feeding the higher energy- and methionine-supplemented diet decreased $\mathrm{N}$ excretion in manure by 56 and $63 \mathrm{~g} \mathrm{~N}$ per hen.
\end{abstract}

KEY WORDS: laying hens, organic diet, methionine, energy, N-balance, performance

\footnotetext{
${ }^{*}$ Supported by Statutory Activity, Project No. 4246.1

${ }^{1}$ Corresponding author: e-mail: jkoreles@izoo.krakow.pl
} 


\section{INTRODUCTION}

The proportion of methionine and sulphur-containing amino acids (SAA) to lysine in organic diets is generally lower as compared with conventional complete diets. Low methionine levels in organic diets can be prevented in part by the use of legume seeds, expellers and maize gluten (Zollitsch and Baumung, 2004) or by an increased level of dietary protein. Insufficient dietary methionine levels and amino acid imbalances in diets increase nitrogen excretion to the environment (Scholtyssek et al., 1991; Summers, 1993). Supplementation with limiting methionine improves laying performance in commercial practice of intensive feeding; response to added methionine is affected by the energy level in a diet (Harms et al., 1998). In organic production, DL-methionine is, however, not listed as an additive allowed in Europe, but its use is being discussed in the USA (Moritz et al., 2005). Despite the minor role of organic egg production in Europe (Windhorst, 2005), in order to protect the environment against a greater mass of manure resulting from lower digestibility and excess of nitrogen $(\mathrm{N})$ in excreta, the possibility of supplementing methionine to organic diets should be discussed and considered.

The effect of methionine supplementation on $\mathrm{N}$ excretion is not fully established in organic diets for egg production. The aim of the present work was to evaluate the effect of dietary energy and DL-methionine (Met) supplementation of organic diets for laying hens on laying performance, egg quality, $\mathrm{N}$ retention and $\mathrm{N}$ excretion in excreta.

\section{MATERIAL AND METHODS}

The trial was conducted with 72 Bovans brown hens from 24 to 53 weeks of age allocated to 4 groups in 18 replicates. Each hen (replicate) was kept in an individual cage $(40 \times 40 \mathrm{~cm})$ with a wire floor to afford possibilities for excreta collection. During the experiment, layers were provided with water and feed ad libitum, and were exposed to a $14 \mathrm{~L}: 10 \mathrm{D}$ lighting schedule with a light intensity of 10 lux.

Hens were not pastured and the feed components used were admissible in organic production, but not certified. Hens were fed the basal organic diets (Table 1) with a lower or higher content of metabolizable energy $\left(\mathrm{ME}_{\mathrm{N}}\right)$ resulting from adding $1 \%$ rape seed oil. The nutrient contents of diets were formulated according to requirements for lying hens (Smulikowska and Rutkowski, 2005), but taking into account organic feeding limitations for feed choice. The basal diets contained a relatively low Met level $\left(2.34 \mathrm{~g} \cdot \mathrm{kg}^{-1}\right)$ and were either not supplemented or supplemented with $0.6 \mathrm{~g} \cdot \mathrm{kg}^{-1}$ DL-Met (98\%, Degussa) to increase total Met and SAA contents to $2.94 \mathrm{~g}$ and $5.21 \mathrm{~g} \cdot \mathrm{kg}^{-1}$, respectively. 
an electronic colorimeter (QCC device, TSS, York, UK) and expressed in Roche scale points. Shell thickness was measured near the equator of the egg using an electronic micrometer (QCT device, TSS, York, UK). Egg shell density (dried shell weight per unit of shell area, $\mathrm{mg} / \mathrm{cm}^{2}$ ) was calculated by Eggware software (TSS, York, UK).

A further 18 eggs from each treatment were collected for measurement of egg shell breaking strength, using an Instron Testing Machine, Model 5542 (Instron Ltd., High Wycombe, England), equipped with a 500 Newton load cell. The eggs were compressed at a constant crosshead speed of $10 \mathrm{~mm} / \mathrm{min}$, and breaking strength was determined at the moment of egg shell fracture.

During 5 days at beginning of the 36th week of age, nitrogen balance was estimated. Feed consumed was measured and total collection of excreta from 5 replicates of each group was carried out. Excreta were weighted each day and stored at $-20^{\circ} \mathrm{C}$. After thawing the excreta were weighted again, homogenized and representative samples for analysis of nitrogen and dry matter content were taken. $\mathrm{N}$ contents in diets and in excreta were estimated by the Kjeldahl method (AOAC, 1990) using a Kjeltec Auto 1030, Tecator. N-balance indices were calculated taking into account amounts of $\mathrm{N}$ ingested and $\mathrm{N}$ excreted.

The amino acid content of diets was analysed in acid hydrolyzates in a colour reaction with the ninhydrin reagent, using a Beckman-System Gold 126 AA automatic analyser. Sulphur-containing amino acids were estimated after preoxidation to sulphone.

Data were subjected to two-way factorial analysis of variance. The significance of differences between means was determined by Duncan's multiple range test and differences were considered significant at $\mathrm{P} \leq 0.05$. Statistical analyses were performed with Statistica 5.0 PL software (Statsoft Inc.).

\section{RESULTS}

During the entire experimental period no deaths were recorded among the hens. Laying performance was affected by the dietary Met level (Table 2). Met supplementation of the diet improved the laying rate, egg weight, daily mass of laid eggs, and feed conversion per egg and $\mathrm{kg}$ of eggs $(\mathrm{P}<0.001)$. Daily feed intake was altered both by dietary Met and energy level $(\mathrm{P}<0.05)$; supplementation of Met increased feed consumption, whereas the higher energy level decreased it. The energy content of the diet did not affect other performance parameters.

Among egg quality parameters (Table 3 ), only yolk mass was increased when hens were fed the Met-supplemented diet, but the relative yolk weight (in \% of egg) was the same as in the unsupplemented diet. Egg shell characteristics 
Table 2. Effect of methionine addition and metabolizable energy level in the diet on performance indices

\begin{tabular}{|c|c|c|c|c|c|c|c|c|}
\hline \multirow[b]{2}{*}{ Item } & \multirow{2}{*}{$\begin{array}{l}\text { Metabo- } \\
\text { lizable } \\
\text { energy level }\end{array}$} & \multicolumn{3}{|c|}{ Methionine addition } & \multirow[b]{2}{*}{ SEM } & \multicolumn{3}{|c|}{ Effect of } \\
\hline & & - & + & mean & & energy & $\begin{array}{c}\text { methio- } \\
\text { nine }\end{array}$ & $\begin{array}{l}\text { inter- } \\
\text { action }\end{array}$ \\
\hline \multirow{3}{*}{ Laying rate, $\%$} & Lower & 89.9 & 95.8 & 92.8 & & & & \\
\hline & Higher & 86.9 & 94.6 & 90.8 & 1.04 & NS & $* * *$ & NS \\
\hline & Mean & 88.4 & 95.2 & & & & & \\
\hline \multirow{3}{*}{ Egg weight, g } & Lower & 54.8 & 59.6 & 57.2 & & & & \\
\hline & Higher & 54.7 & 58.6 & 56.7 & 0.638 & NS & $* * *$ & NS \\
\hline & Mean & 54.7 & 59.1 & & & & & \\
\hline \multirow{3}{*}{$\begin{array}{l}\text { Daily mass of eggs, } g \\
\text { per hen }\end{array}$} & Lower & 49.2 & 57.0 & 53.1 & & & & \\
\hline & Higher & 47.6 & 55.5 & 51.5 & 1.14 & NS & $* * *$ & NS \\
\hline & Mean & 48.4 & 56.3 & & & & & \\
\hline \multirow{3}{*}{$\begin{array}{l}\text { Daily feed intake, g } \\
\text { per hen }\end{array}$} & Lower & 121 & 123 & 122 & & & & \\
\hline & Higher & 120 & 121 & 121 & 0.336 & $*$ & $*$ & NS \\
\hline & Mean & 121 & 122 & & & & & \\
\hline \multirow{3}{*}{ Feed, g per 1 egg } & Lower & 135 & 128 & 132 & & & & \\
\hline & Higher & 138 & 128 & 133 & 1.39 & NS & $* * *$ & NS \\
\hline & Mean & 137 & 128 & & & & & \\
\hline \multirow{3}{*}{$\begin{array}{l}\text { Feed, kg per } 1 \mathrm{~kg} \text { of } \\
\text { eggs }\end{array}$} & Lower & 2.46 & 2.15 & 2.31 & & & & \\
\hline & Higher & 2.53 & 2.19 & 2.36 & 0.048 & NS & $* * *$ & NS \\
\hline & Mean & 2.50 & 2.17 & & & & & \\
\hline
\end{tabular}

NS-P $>0.05, *-\mathrm{P} \leq 0.05, * * *-\mathrm{P} \leq 0.001$

were not changed when the methionine or energy content in the diet was increased.

The positive effect of the higher dietary energy level and methionine supplementation on nitrogen balance (Table 4) was statistically confirmed in the case of $\mathrm{N}$ retention in $\%$ of $\mathrm{N}$ intake $(\mathrm{P}<0.05$ and $\mathrm{P}<0.01)$. Moreover, supplementing the diet with Met increased daily $\mathrm{N}$ retention and decreased $\mathrm{N}$ content in excreta $(\mathrm{P}<0.05)$. In relation to daily $\mathrm{N}$ excretion the differences were not statistically confirmed (Table 4).

\section{DISCUSSION}

In the present experiment, the proportion of dietary Met to lysine (Lys) in the organic basal diet at both energy levels was 28.1. For that reason the diet could be classified as Met inadequate when compared the value of 43.6 recommended in intensive hen feeding (Smulikowska and Rutkowski, 2005) and the ideal ratio of to 47.0 on a true digestible basis for maximum egg mass (Bregendahl et al., 2008). 
Table 3. Effect of methionine addition and metabolizable energy level on egg quality

\begin{tabular}{|c|c|c|c|c|c|c|c|c|}
\hline \multirow[b]{2}{*}{ Item } & \multirow{2}{*}{$\begin{array}{l}\text { Metaboli- } \\
\text { zable energy } \\
\text { level }\end{array}$} & \multicolumn{3}{|c|}{ Methionine addition } & \multirow[b]{2}{*}{ SEM } & \multicolumn{3}{|c|}{ Effect } \\
\hline & & - & + & mean & & energy & $\begin{array}{l}\text { methio- } \\
\text { nine }\end{array}$ & $\begin{array}{l}\text { inter- } \\
\text { action }\end{array}$ \\
\hline \multirow{3}{*}{ Albumen height, mm } & Lower & 6.59 & 6.47 & 6.53 & & & & \\
\hline & Higher & 6.61 & 4.76 & 6.68 & 0.142 & NS & NS & NS \\
\hline & Mean & 6.60 & 6.61 & & & & & \\
\hline \multirow{3}{*}{ Haugh Units } & Lower & 81.8 & 79.5 & 80.6 & & & & \\
\hline & Higher & 81.0 & 80.6 & 80.8 & 0.957 & NS & NS & NS \\
\hline & Mean & 81.4 & 80.0 & & & & & \\
\hline \multirow{3}{*}{$\begin{array}{l}\text { Yolk colour, points in } \\
\text { Roche scale }\end{array}$} & Lower & 3.17 & 3.42 & 3.29 & & & & \\
\hline & Higher & 3.17 & 3.17 & 3.17 & 0.100 & NS & NS & NS \\
\hline & Mean & 3.17 & 3.29 & & & & & \\
\hline \multirow{3}{*}{ Yolk weight, g } & Lower & 16.1 & 16.9 & 16.5 & & & & \\
\hline & Higher & 16.1 & 17.7 & 16.9 & 0.226 & NS & $* *$ & NS \\
\hline & Mean & 16.1 & 17.3 & & & & & \\
\hline \multirow{3}{*}{$\begin{array}{l}\text { Relative yolk weight, } \\
\% \text { of egg weight }\end{array}$} & Lower & 28.7 & 27.8 & 28.2 & & & & \\
\hline & Higher & 28.6 & 28.5 & 28.6 & 0.281 & NS & NS & NS \\
\hline & Mean & 28.6 & 28.2 & & & & & \\
\hline \multirow{3}{*}{$\begin{array}{l}\text { Egg shell thickness, } \\
\mu \mathrm{m}\end{array}$} & Lower & 393 & 393 & 393 & & & & \\
\hline & Higher & 399 & 383 & 391 & 5.06 & NS & NS & NS \\
\hline & Mean & 396 & 388 & & & & & \\
\hline \multirow{3}{*}{$\begin{array}{l}\text { Egg shell density, } \\
\mathrm{mg} / \mathrm{cm}^{2}\end{array}$} & Lower & 97.7 & 92.3 & 95.0 & & & & \\
\hline & Higher & 94.1 & 92.5 & 93.3 & 1.12 & NS & NS & NS \\
\hline & Mean & 95.9 & 92.4 & & & & & \\
\hline \multirow{3}{*}{$\begin{array}{l}\text { Egg shell breaking } \\
\text { strength, } \mathrm{N}\end{array}$} & Lower & 37.6 & 35.3 & 36.4 & & & & \\
\hline & Higher & 37.9 & 36.9 & 37.4 & 1.06 & NS & NS & NS \\
\hline & Mean & 37.7 & 36.1 & & & & & \\
\hline
\end{tabular}

NS-P $>0.05, * *-\mathrm{P} \leq 0.01$

Met supplementation of the organic diet in the present experiment favourably increased the Met/Lys ratio to 35.3.

The Met-to-energy ratios in the unsupplemented or Met-supplemented lowerenergy diet averaged $0.21 \mathrm{~g} / 1 \mathrm{MJ} \mathrm{ME}_{\mathrm{N}}$ or $0.26 \mathrm{~g} / 1 \mathrm{MJ} \mathrm{ME}_{\mathrm{N}}$. In the higher-energy diets these ratios were $0.20 \mathrm{~g} / 1 \mathrm{MJ} \mathrm{ME}_{\mathrm{N}}$ and $0.25 \mathrm{~g} / 1 \mathrm{MJ} \mathrm{ME}_{\mathrm{N}}$, respectively. The ratios were lower as compared with the recommended $0.30 \mathrm{~g}$ methionine/ $1 \mathrm{MJ} \mathrm{ME}_{\mathrm{N}}$ for intensive laying hen feeding (Smulikowska and Rutkowski, 2005). In both cases the lower Met content in basal diets was a result of feed choices for an organic diet and the assumption of not attaining the highest egg performance in organic production.

The amino acid deficiency in the organic diets used in this experiment may explain the effects of adding Met, e.g., improvement of laying rate, egg weight, feed conversion and feed intake. These results correspond with the efficiency of 
Table 4. Effect of methionine addition and dietary metabolizable energy level in the diet on nitrogen balance

\begin{tabular}{|c|c|c|c|c|c|c|c|c|}
\hline \multirow[b]{2}{*}{ Item } & \multirow{2}{*}{$\begin{array}{l}\text { Metabo- } \\
\text { lizable } \\
\text { energy level }\end{array}$} & \multicolumn{3}{|c|}{ Methionine addition } & \multirow[b]{2}{*}{ SEM } & \multicolumn{3}{|c|}{ Effect of: } \\
\hline & & - & + & mean & & energy & $\begin{array}{c}\text { methio- } \\
\text { nine }\end{array}$ & $\begin{array}{l}\text { inter- } \\
\text { action }\end{array}$ \\
\hline \multirow{4}{*}{$\begin{array}{l}\mathrm{N} \text { intake, } \mathrm{g} / \text { hen per } \\
\text { day }\end{array}$} & Lower & 3.40 & 3.34 & 3.37 & 0.082 & & & \\
\hline & Higher & 3.34 & 3.43 & 3.38 & & NS & NS & NS \\
\hline & Mean & 3.37 & 3.39 & & & & & \\
\hline & Lower & 63.4 & 62.7 & 63.1 & & & & \\
\hline \multirow{2}{*}{$\begin{array}{l}\mathrm{N} \text { content in } \\
\text { excreta, } \mathrm{g} / \mathrm{kg} \text { of dry } \\
\text { matter }\end{array}$} & Higher & 64.1 & 58.3 & 61.2 & 0.788 & NS & $*$ & NS \\
\hline & Mean & 63.8 & 60.5 & & & & & \\
\hline \multirow{3}{*}{$\begin{array}{l}\mathrm{N} \text { excretion, g/bird } \\
\text { per day }\end{array}$} & Lower & 2.62 & 2.47 & 2.54 & & & & \\
\hline & Higher & 2.48 & 2.28 & 2.38 & 0.063 & NS & NS & NS \\
\hline & Mean & 2.55 & 2.37 & & & & & \\
\hline \multirow{3}{*}{$\begin{array}{l}\mathrm{N} \text { retention, } \mathrm{g} / \text { bird } \\
\text { per day }\end{array}$} & Lower & 0.767 & 0.871 & 0.819 & & & & \\
\hline & Higher & 0.783 & 1.166 & 0.974 & 0.056 & NS & $*$ & NS \\
\hline & Mean & 0.775 & 1.019 & & & & & \\
\hline \multirow{3}{*}{$\begin{array}{l}\mathrm{N} \text { retained } \\
\text { as } \% \text { of } \mathrm{N} \text { intake }\end{array}$} & Lower & 22.5 & 26.0 & 24.3 & & & & \\
\hline & Higher & 23.4 & 34.0 & 28.8 & 1.36 & $*$ & $* *$ & NS \\
\hline & Mean & 22.9 & 30.0 & & & & & \\
\hline
\end{tabular}

NS-P $>0.05, *$ - $\mathrm{P} \leq 0.05, * *-\mathrm{P} \leq 0.01$

Met supplementation of hen diets for intensive production (Harms and Russel, 1998). A non-significant tendency towards a lower laying rate and egg mass in hens fed the energy-supplemented diet could be explained as a result of slightly reduced feed intake. Consequently, the Met insufficiency in the ration could be increased. Both egg weight and yolk mass were increased as a result of adding Met and also, but only numerically, by the higher energy level. In both cases, however, the relative weight of the yolk was not changed. In an experiment with Leghorn hens, increased dietary levels of energy and amino acids significantly increased egg weight (Wu et al., 2007).

The positive effect of higher energy content on $\mathrm{N}$ utilization may suggest a small energy insufficiency in the organic diet. Satisfactory N retention in hens fed the diet supplemented both with energy and Met as compared with the other groups was not ultimately confirmed by feed utilization ( $\mathrm{g}$ of feed per $\mathrm{g}$ of laid eggs) for the whole experimental period. This can probably be explained as a consequence of the short N-balance estimation period (5 days).

Better $\mathrm{N}$ utilization from the Met-supplemented diet in our experiment was a result of a smaller excess of amino groups from degradation of amino acids. In poultry, in unbalanced diets this excess is converted to uric acid and excreted (Scholtyssek et al., 1991; Goldstein and Skadhauge, 2000). It is well known that poultry manure has 
a high concentration of soluble nitrogen forms, so the potential pollution of ground water with nitrates is a serious problem in poultry production (Archer, 1993).

Taking into account the differences in average daily nitrogen excretion, it can be calculated that during a 50-week period (350 days) of laying, one hen fed a higher-energy or Met-supplemented diet excreted, on average, 56 or $63 \mathrm{~g} \mathrm{~N}$ less, respectively, than a hen fed the unsupplemented basal organic diet. These amounts calculated for one building of 3000 hens in organic production give a reduction of 168 to $189 \mathrm{~kg}$ of $\mathrm{N}$ excreted to environment.

\section{CONCLUSIONS}

The results obtained with hens fed an organic diet supplemented with methionine and with a higher energy level may point to better laying performance and decreased $\mathrm{N}$ excretion to the environment. Synthetic methionine as a potential dietary supplement in organic egg production must be discussed.

\section{REFERENCES}

Archer J., 1993. Avoiding pollution from poultry manure. World Poultry Sci. J. 49, 167-170

AOAC, 1990. Association of Official Analytical Chemists, Official Methods of Analysis. 15 $5^{\text {th }}$ Edition. Arlington, VA

Bregendahl K., Roberts S.A., Kerr B., Hoehler D., 2008. Ideal ratios of isoleucine, methionine, methionine plus cystine, threonine, tryptophan and valine relative to lysine for White Leghorntype laying hens of twenty-eight to thirty-four weeks of age. Poultry Sci. 87, 744-758

European Table of Energy Values for Poultry Feedstuffs, 1989. WPSA, Wageningen

Goldstein D.L., Skadhauge E., 2000. Renal and extra-renal regulation of body fluid composition, In: G.C. Whittow (Editor). Avian Endocrinology. Chapter 11. $5^{\text {th }}$ Edition. Academic Press, NY

Harms R.H., Russell G.B., Harlow H., Ivey F.J., 1998. The influence of methionine on commercial laying hens. J. Appl. Poultry Res. 7, 45-52

Moritz J.S., Parsons A.S., Buchanan N.P., Baker N.J., Jaczynski J., Gekara O.J., Bryan W.B., 2005. Synthetic methionine and feed restriction effects on performance and meat quality of organically reared broiler chickens. J. Appl. Poultry Res. 14, 521-535

Scholtyssek S., Feuerstein D., Kutritz B., 1991. Experiments to optimize protein conversion and nitrogen excretion in feeding laying hens. Arch. Geflügelk. 55, 134-141

Smulikowska S., Rutkowski A. (Editors), 2005. Recommended Allowances and Nutritive Value of Feedstuffs. Poultry Feeding Standards (in Polish). $4^{\text {th }}$ Edition. The Kielanowski Institute of Animal Physiology and Nutrition, PAN. Jabłonna, and Polish Branch of WPSA (Poland)

Summers J.D., 1993. Reducing nitrogen excretion of the laying hen by feeding lower crude protein diets. Poultry Sci. 72, 1473-1478

Windhorst H.W., 2005. Development of organic egg production and marketing in the EU. World Poultry Sci. J. 61, 451-461

Wu G., Bryant M.M., Gunawardana P., Roland D.A., 2007. Effect of nutrient density on performance, egg components, egg solids, egg quality, and profits in eight commercial Leghorn stains during phase one. Poultry Sci. 86, 691-697

Zollitsch W., Baumung R., 2004. Protein supply for organic poultry: options and shortcomings. In: Proceedings of $2^{\text {nd }}$ SAFO Workshop. Witzenhausen (Germany), pp. 153-159 